\title{
Editorial
}

Neste número, apresentamos uma seleção de artigos, expressiva do movimento de renovação geracional nas ciências sociais que, de alguma forma, se relaciona com a grande expansão de posições intelectuais no Brasil contemporâneo.

Apresentando-se como candidata para divulgação de pesquisas feitas por jovens investigadores, a direção imprimida pelos atuais editores da Latitude é a de abrir as portas para diferentes tipos de abordagens e objetos de investigação. Com a expansão recente, no Brasil, de posições intelectuais em instituições com diferentes perfis, acreditamos que há espaço para se ampliar, ainda mais, o leque de arenas para a publicidade de investigações promissoras, mas com dificuldades de serem percebidas como relevantes. Desejamos fazer parte dos esforços para a disseminação de novas visadas, enriquecendo o acervo de questões e informações disponíveis para nos orientarmos nas intensas transformações humanas nas quais estamos imersos e, não raras vezes, sem conhecimentos adequados para nos guiarmos.

Os trabalhos que figuram neste número, além de exprimir interesses de pesquisadores de diferentes regiões do país, indicam um grau significativo de circulação de informações no contexto latino-americano. Desejamos estimular ainda mais essa direção editorial.

O trabalho de Thaís Marinho intitulado "Os Desafios da Razão: entre a omissão e o respeito" nos oferece um exemplo do estágio alcançado pelo diálogo entre sociologia e antropologia, expresso no esforço de compreender formas de reconhecimento vinculadas ao ideal da singularidade cultural entre os Kalunga. Visando escapar de um modelo de compreensão das auto-imagens grupais e individuais que opõe o particular e o universal como limites substanciais das formas de identificação, a autora intenta mudar o ângulo da questão, apresentando a dinâmica da formação de auto-imagens grupais como parte do trânsito de ideais humanos como condição que tornou possível a adoção do multiculturalismo como lógica de orientação e de organização social dos ideais e das imagens de mundo. Aproximando o tema da cultura e da economia, acaba desenvolvendo a ideia, dentre outras, de que a linguagem da busca por igualdade toma a forma do particularismo como um ideal que fundamenta jogos de poder.

Em seguida temos o trabalho de Segura sobre a dinâmica da economia petrolífera argentina, atendo-se a alterações na estrutura de precificação do petróleo desde os anos 70 até o presente. O seu trabalho permiti-nos ter elementos mais realistas para realizar uma adequada avaliação retrospectiva dos rumos da relação entre Estado e mercado na Argentina diante do fenômeno da nacionalização da empresa petrolífera espanhola YPF, em 2012. Do ponto de vista de nós, que vimos os fatos acontecerem, temos a chance de ver a análise como uma 
avaliação do campo de possíveis estabelecido para os agentes governamentais argentinos diante de valores que foram se tornando inconciliáveis para a manutenção de uma estrutura de poder estatal nacional argentina. De modo específico, um dos aspectos que se destaca no texto é a análise da lógica de precificação do petróleo atendo-se ao movimento de crescente dependência da estrutura de poder das finanças, ficando em segundo plano, a importância do aumento da produtividade como critério de valorização da commoditie.

No terceiro artigo, encontramos relações com o primeiro, especialmente a discussão sobre as funções de auto-identificação no mundo contemporâneo. Avaliando lógicas comunitárias do candomblé, o artigo intitulado "Do Bifrontismo de Jano: Notas para a reflexão sobre os processos de Reflexividade, Síntese e ReSignificação de Memórias Sociais", de Gutemberg, traz uma análise sobre as condições contemporâneas de formação das identidades e aspectos de suas lógicas de transmissão. O problema do reconhecimento é colocado na esteira do que podemos chamar de uma linhagem de reflexões que crescentemente tem aproximado os universos de símbolos representativos do que, anteriormente, era visto de maneira opositiva, como lógica das emoções e lógica das razões. No caso, as aproximações desses campos semânticos estão estreitamente vinculadas à importância teórico-metodológica de noções como recursividade, habitus, mimese que auxiliam a interpretação das visões que os agentes observados têm de seus sensos identitários.

O penúltimo artigo intitulado "Entre o Deus e o Mundo: norma e desvio numa comunidade religiosa" de Rocha Neto traz - como mais um sintoma de um dos valores que dão forma ao envolvimento cultural dos pesquisadores atuais uma análise orientada pelo problema da compreensão das dinâmicas comunitárias. A reflexão está prioritariamente orientada para a relação entre busca de amorpróprio e a formação de dinâmicas de controles normativos - sistemas de punições e culpas - concentrados nas mãos de lideranças religiosas. O problema mantém relação com outros trabalhos desse número na medida em que é patente a importância do problema da reavaliação dos critérios de inserção comunitária entre jovens no interior da sociabilidade de uma Igreja vinculada à Assembleia de Deus, dando-nos uma imagem de como se dá a negociação e a ressignificação tanto dos controles morais quanto das formas de premiação e estigmatização da imagem individual no interior de um grupo religioso.

O artigo de Martins e Amaral visa trazer esclarecimentos de algumas questões teóricas envolvendo a noção de habitus propostas por Pierre Bourdieu a luz de uma comparação com as perspectivas de Thèvenot e Boltanski. No artigo intitulado "O habitus em Bourdieu e a teoria da justificação de Boltanski e Thévenot" podemos ter mais uma visada sobre a obra de Bourdieu, mas agora a luz de contemporâneos seus no campo sociológico francês, dando-nos a oportunidade de ter maior conhecimento sobre os ideais de conhecimento na sociologia francesa que se consolida contemporaneamente. 
Por fim, o último artigo traz uma contribuição para a compreensão das práticas de agentes referenciadas por políticas públicas de "desenvolvimento sustentável". Turri e Lima mostram como os estímulos à organização de "Arranjos Produtivos Locais", formato da coordenação de diferentes instituições orientadas para a busca de oportunidades econômicas "sustentáveis", incentivadas pelo governo, estão entremeados às lógicas valorativas não-econômicas de modelação social. A necessidade de dar conta dos modos de orientação econômicos em contextos nos quais a elevada legitimidade de ordens de poder não exclusivamente capitalistas se impõe, faz com que os autores escolham manusear ferramentas teóricas como as teorias da sociologia econômica e da estruturação, de Granovetter e Giddens, respectivamente, visando oferecer uma imagem do que acontece na implantação de Arranjos Produtivos Locais, e da estrutura de conflitos entre agentes, instituições e ideais em jogo, sob o céu estatal que se oferece para protegêlos.

Esperamos que os trabalhos possam ser úteis. Reforçamos o convite para o envio de trabalhos para a revista Latitude, aberta para a avaliação de artigos, resenhas e entrevistas relativas a diferentes campos das ciências humanas, em fluxo contínuo.

\section{Os editores.}

